\title{
Biomechanical comparison of a new handy tension band with malleolar screw, bicortical screw and conventional tension band for the fixation of transverse medial malleolar fractures
}

\author{
Transvers medial malleolar kırıklarının sabitlenmesinde yeni kullanışlı bir gergi bandının \\ malleolar vida, bikortikal vida ve geleneksel gergi bandı ile biyomekanik karşılaştırması
}

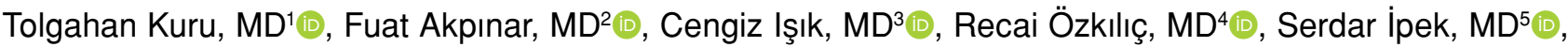 \\ Ibrahim Mutlu, $\mathrm{MD}^{6}\left(\mathbb{D}\right.$, Hasan Kızılay, $\mathrm{MD}^{7}$ (D)
}

\begin{abstract}
${ }^{1}$ Department of Orthopedics and Traumatology, Onsekiz Mart University Medical Faculty, Çanakkale, Turkey
${ }^{2}$ Department of Orthopedics and Traumatology, Medeniyet University Medical Faculty, İstanbul, Turkey

${ }^{3}$ Department of Orthopedics and Traumatology, Abant Izzet Baysal University Medical Faculty, Bolu, Turkey

${ }^{4}$ Department of Orthopedics and Traumatology, Düzce Atatürk State Hospital, Düzce, Turkey

${ }^{5}$ Department of Orthopedics and Traumatology, Aksaray University Training and Research Hospital, Aksaray, Turkey

${ }^{6}$ Department of Biomedical Engineering, Kocaeli University Technology Faculty, Kocaeli, Turkey

${ }^{7}$ Department of Orthopedics and Traumatology, Gerede State Hospital, Bolu, Turkey
\end{abstract}

\begin{abstract}
Objectives: This study aims to compare the biomechanical features of a new handy tension band with the malleolar screw, bicortical screw and conventional tension band for the fixation of transverse medial malleolar fractures.
\end{abstract}

Materials and methods: This study used 20 Kirschner wires, five cerclage wires, six double-hole U pins, six cortical screws, six malleolar screws, three malleolar clamps and one osteotomy set. A total of 24 tibias of two-year-old cows were obtained and stripped from soft tissue. Each tibia was cut with an electric saw at $15 \mathrm{~cm}$ proximal to the tibiotalar joint surface and the proximal tibia sections were discarded. A transverse fracture line was created with an osteotome on the medial malleolus. The tibias were separated into four groups with six tibias in each group. The distal tibia medial malleolar transverse fragments were fixed under guidance of fluoroscopy with the malleolar screw, bicortical screw, conventional tension band and the new handy tension band.

Results: In the application of both transverse and axial force, the new handy tension band resisted higher forces in respect of catastrophic damage force being more resistant compared to the bicortical screw, malleolar screw, and conventional tension band. However, in respect of the $2 \mathrm{~mm}$ displacement force of the forces applied in the axial and transverse sections, no difference was determined between the handy tension band and the other three implants.

Conclusion: The new handy tension band seems to be more successful when biomechanically compared with the other implants.

Keywords: Bicortical screw, biomechanics, medial malleolar fracture, tension band.
ÖZ

Amaç: $\mathrm{Bu}$ çalışmada, transvers medial malleolar kırıklarının sabitlenmesinde yeni kullanışlı bir gergi bandının biyomekanik özellikleri malleolar vida, bikortikal vida ve geleneksel gergi bandı ile karşılaştırıldı.

Gereç ve yöntemler: Çalışmada $20 \mathrm{Kirschner} \mathrm{teli,} \mathrm{beş} \mathrm{serklaj}$ teli, altı çift delikli U pin, altı kortikal vida, altı malleolar vida, üç malleolar klemp ve bir osteotomi seti kullanıldı. İki yaşında sığırların toplam 24 tibiası elde edilerek yumuşak dokudan sıyrıldı. Her tibia elektrikli bir testere ile tibiotalar eklem yüzeyinin $15 \mathrm{~cm}$ proksimalinde kesildi ve proksimal tibia bölümleri atıldı. Medial malleolus üzerinde osteotom ile transvers bir kırık hattı oluşturuldu. Tibialar her grupta altı tibia olmak üzere dört gruba ayrıldı. Distal tibia medial malleolar transvers fragmanları floroskopi kılavuzluğunda malleolar vida, bikortikal vida, geleneksel gergi bandı ve yeni kullanışlı gergi bandı ile sabitlendi.

Bulgular: Hem transvers hem de aksiyel kuvvet uygulamasında, yeni kullanışlı gergi bandı katastrofik hasar kuvveti açısından daha yüksek kuvvetlere direnç göstermiş olup bikortikal vida, malleolar vida ve geleneksel gergi bandına kıyasla daha dirençliydi. Ancak aksiyel ve transvers kesitlere uygulanan kuvvetlerin $2 \mathrm{~mm}$ deplasman kuvveti açısından yeni kullanışlı gergi bandı ve diğer üç implant arasında farklılık saptanmadı.

Sonuç: Yeni kullanışlı gergi bandı diğer implantlarla biyomekanik olarak karşılaştırıldığında daha başarılı görünmektedir.

Anahtar sözcükler: Bikortikal vida, biyomekanik, medial malleolar kırık, gergi bandı.

Received: June 13, 2019 Accepted: August 27, 2019 Published online: October 24, 2019

Correspondence: Tolgahan Kuru, MD. Onsekiz Mart Üniversitesi Tıp Fakültesi Ortopedi ve Travmatoloji Anabilim Dalı, 17020 Çanakkale, Turkey. Tel: +90 286-21800 18 e-mail: mdtolgahankuru@gmail.com 
Ankle fractures are one of the most frequently seen injuries of the musculoskeletal system, and an increase in frequency has been seen in recent years. ${ }^{[1-3]}$ The treatment of ankle fractures is controversial because of the anatomic structure of the joint and the complex biomechanical characteristics. The aim of treatment is to obtain anatomic reduction, to protect this reduction until bone healing, and to regain the pre-injury level of normal function with pain-free movements of the ankle joint. Studies have shown that the prognosis is more positive with the full anatomic reduction. ${ }^{[4-6]}$ Surgical outcomes are usually good for fixing medial malleolar fractures. In most studies, there is an agreement on that the best results to restore anatomic parameters in displaced unstable ankle fractures are obtained with internal fixation and open reduction. ${ }^{[7]}$ There are various new fixation models developed for this type of fractures including plate fixation, screws, sleds, absorbable implants and tension band wiring systems. ${ }^{[8-10]}$ However, there is still no recognized gold standard for fixation of medial malleolus fractures. Kirschner wire (K-wire) fixation with a tension band construct, partially threaded $\mathrm{K}$ wire fixation, and partially threaded cancellous screws have been used for this purpose. ${ }^{[11,12]}$ Fixation of the medial malleolus is also widely performed using bicortical partially threaded cancellous lag screws, which has been shown to be biomechanically stronger compared to unicortical cancellous lag screws. ${ }^{[12-14]}$ Implant migration, premature loosening, and implant skin irritation can be seen in malleolar fractures treated by conventional methods. Such complications and surgeons' desire for early functional use with stable fixation lead to the development of new surgical procedures and implant designs. In this study, we aimed to compare the biomechanical features of a new handy tension band with the malleolar screw, bicortical screw and conventional tension band for the fixation of transverse medial malleolar fractures.

\section{MATERIALS AND METHODS}

This study was conducted at Abant İzzet Baysal University Medical Faculty between February 2015 and February 2016. With the financial support of the Scientific Research Project of Abant Izzet Baysal University, the study used $20 \mathrm{~K}$-wires, five cerclage wires, six double-hole U pins (TST Tibbi Aletler San. ve Tic. Ltd. Şti., Pendik, İstanbul, Turkey), six cortical screws (TST brand), six malleolar screws (TST brand), three malleolar clamps and one osteotomy set. Tibias of two-year-old cows were used considering that they have same or close to each other bone densities. A total of 24 bovine tibia were obtained and stripped of soft tissue. Each tibia was cut with an electric saw at $15 \mathrm{~cm}$ proximal to the tibiotalar joint surface and the proximal tibia sections were discarded. In the 24 distal sections, a transverse fracture line was created with an osteotome on the medial malleolus.

The tibias were separated into four groups each consisting of six tibias. The distal tibia medial malleolar transverse fragments were fixed under fluoroscopy guidance with the procedures of bicortical screw, conventional tension band, new handy tension band system and malleolar screw, respectively (Figure 1).

The new handy tension band has been designed for medial malleolus, olecranon and patella fractures. It has two separate holes, one for round and the other for dynamic compression. Additional parts are suitable for bending to adjust bone anatomy (Figure 2).

After the transverse malleolar fracture was reduced, medial malleolus is drilled using a $2 \mathrm{~mm}$

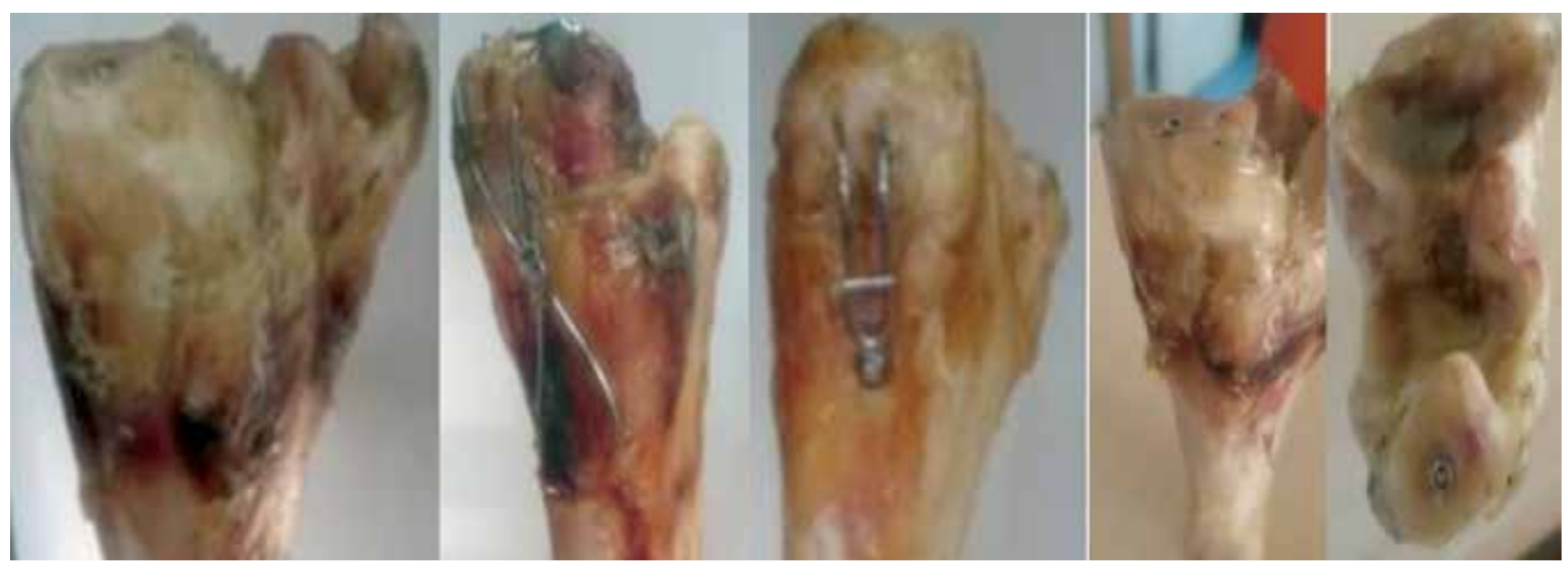

Figure 1. Fixation with bicortical screw, tension band, handy tension band system and malleolar screw procedures. 


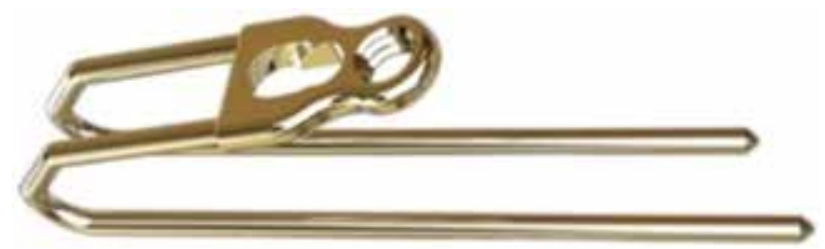

Figure 2. New handy tension band system.

K-wire and the pins of the implant is passed through from the distal malleolus. The two pins of the implant are inserted into the drilled holes with the help of impactor. After drilling with $2.7 \mathrm{~mm}$ drill, fixation is completed by placing the appropriate screw. The implant can be applied with a $3 \mathrm{~cm}$ incision through the medial malleolus.

The new handy tension band system is made of medical stainless steel material, with different shapes and bends, in six different types consisting of cerclage and screws. In the handy tension band, a portion of the implant is fixed eccentrically to the convex side of the fractured bone. When an axial load is applied, the part of the implant on the tension side neutralizes the forces under the axial load, because the curved structure has compression and tension sides. The opposite part of the implant provides cortical contact on the compression side. This design prevents the distortion of the reduction.

In the Biomechanical Laboratory of the Engineering Faculty of Kocaeli University, by shaping with an appropriate cup, a polyethylene
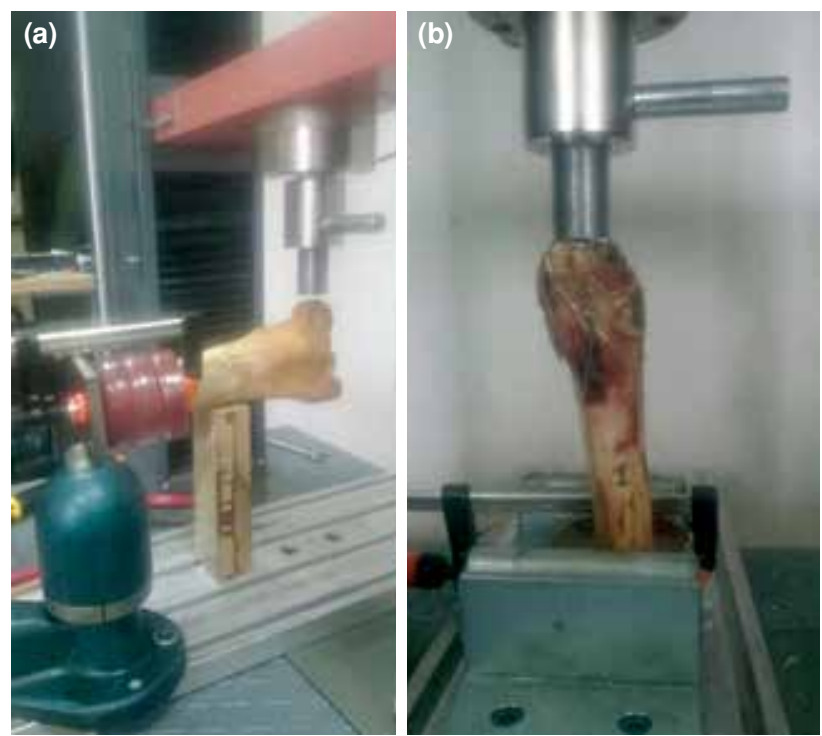

Figure 3. (a) Malleolar screw transverse force application, (b) classic tension band axial force application. mould was frozen in the proximal part of the samples in the bones to which axial and transverse forces were to be applied (Figure 3). The tensile force was applied to the distal and proximal of the bone in a manner so as not to cross the osteotomy line with the polyethylene mould resistant to biomechanical deformation and was then analyzed (Figure 4). Biomechanical data were obtained of the axial loading and deformation of the prepared groups by testing with the test device which could perform digital analysis.

The analyses were based on three parameters of catastrophic damage force, resistance, and $2 \mathrm{~mm}$ displacement force. The catastrophic damage force was calculated on the basis of the maximum force applied causing irreversible damage to the bones. Resistance was calculated with the linear angle on a graph (force/time). The $2 \mathrm{~mm}$ displacement force was defined as the force creating $2 \mathrm{~mm}$ displacement in the bones.

A sample size of 24 (six subjects per group) was calculated with $\mathrm{G}^{*}$ Power 3.0 (Heinrich-HeineUniversität Düsseldorf, Düsseldorf, Germany) program to provide $\geq 80 \%$ power and $5 \%$ alpha error to detect the effect of the new handy tension band against the other methods.

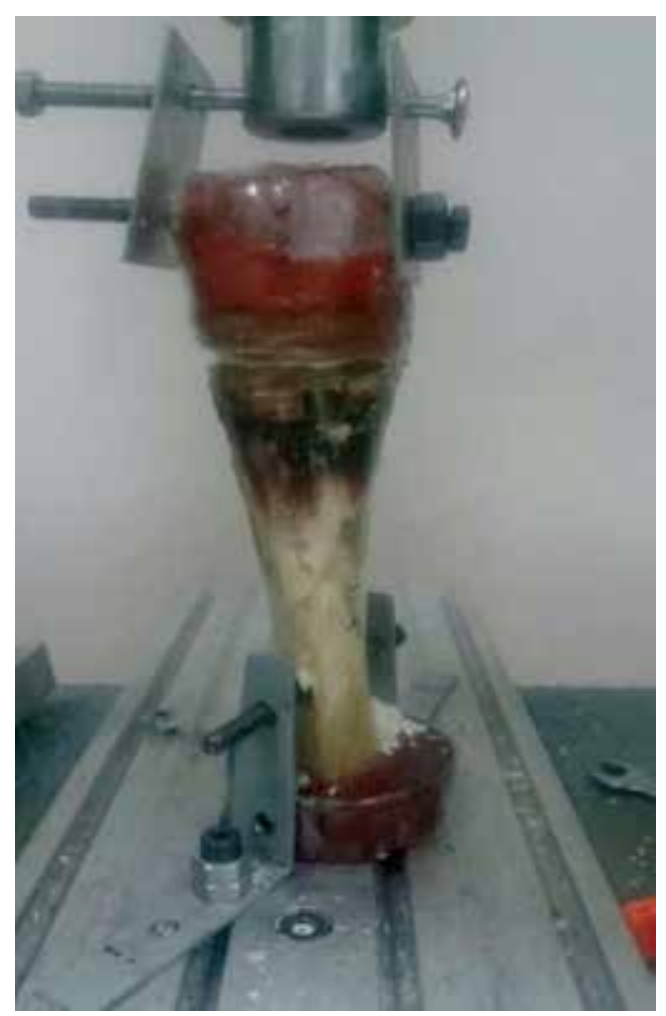

Figure 4. Bicortical screw tensile force application. 


\section{Statistical analysis}

The biomechanical data obtained were analyzed using the SPSS version 11.0 software (SPSS Inc., Chicago, IL, USA). The conformity of the data to normal distribution was examined visually (histogram and probability graphs) and with analytical methods (Kolmogorov-Smirnov/Shapiro-Wilk tests). Descriptive analyses were performed using mean \pm standard deviation for variables with normal distribution. In the comparison of the biomechanical data of the fixation methods, the analysis of variance (ANOVA) method was used. When differences were determined between groups, Bonferroni correction and post-hoc analyses were applied. Due to the distribution in the post-hoc analyses, the Tukey test was used. A $p$ value of $<0.05$ was accepted as statistically significant.

\section{RESULTS}

In the ANOVA test analyses, a statistically significant difference was determined between the malleolar screw, bicortical screw, conventional tension band and new handy tension band in each of the parameters of catastrophic damage force, resistance, and $2 \mathrm{~mm}$ displacement force in the forces applied to the bones in the transverse section (Table I).
In respect of the catastrophic damage force, new handy tension band system had statistically significantly greater resistance of up to mean 603.5 $\mathrm{N}$ than the bicortical screw method $(\mathrm{p}=0.026)$, of 1589 $\mathrm{N}$ than conventional tension band $(\mathrm{p}=0.001)$, and of $1057 \mathrm{~N}$ than the malleolar screw method $(\mathrm{p}=0.003)$.

When the transverse force was applied and the difference between the methods was examined in respect of resistance with post-hoc analyses, new handy tension band was found to be more resistant by mean $92.6 \mathrm{~N} / \mathrm{mm}$ than the bicortical screw method $(\mathrm{p}=0.003)$, by $77.5 \mathrm{~N} / \mathrm{mm}$ than conventional tension band ( $\mathrm{p}=0.005)$, and by $26.5 \mathrm{~N} / \mathrm{mm}$ than the malleolar screw $(p=0.178)$. The differences determined with the bicortical screw and conventional tension band were found to be statistically significant; while the difference with the malleolar screw method was not statistically significant.

An examination of the relationship between the fixation method and the $2 \mathrm{~mm}$ displacement force when the transverse force was applied showed a statistically significantly low correlation in new handy tension band compared to conventional tension band $(\mathrm{p}<001)$, and malleolar screw $(\mathrm{p}<0.001)$. No statistically significant difference was determined with the bicortical screw $(\mathrm{p}=0.829)$.

TABLE I

Comparison of catastrophic damage force, resistance, and $2 \mathrm{~mm}$ displacement force of methods in transverse section

\begin{tabular}{lccccc}
\hline Transverse force & Mean \pm SD & SE & $95 \% \mathrm{Cl}$ & Min-Max & 0.001 \\
\hline Catastrophic damage $(\mathrm{N})$ & & & & & \\
Bicortical screw & $2,958.5 \pm 140.7$ & 99.5 & $1694.2-4222.8$ & $2859-3058$ \\
Tension band & $1,973 \pm 131.5$ & 93 & $791.3-3154.7$ & $1880-2066$ \\
Handy tension band & $3562 \pm 17$ & 12 & $3,409.5-3714.5$ & $3550-3574$ \\
Malleolar screw & $2,505 \pm 148.5$ & 105 & $1170.8-3839.2$ & $2400-2610$ \\
Total & $2,749.6 \pm 631.6$ & 223.3 & $2,221.6-3277.7$ & $1880-3574$ \\
Resistance (N/mm) & & & & & 0.002 \\
Bicortical screw & $86 \pm 7.8$ & 5.5 & $15.9-156.2$ & $80.5-91.6$ & $100.4-101.8$ \\
Tension band & $101.1 \pm 1$ & 0.7 & $92.4-109.8$ & $173.3-184$ \\
Handy tension band & $178.6 \pm 7.6$ & 5.4 & $110.4-246.9$ & $140-164.2$ \\
Malleolar screw & $152.1 \pm 17.1$ & 12.1 & $-1.4-305.5$ & $80.5-184$ \\
Total & $129.5 \pm 40.8$ & 14.4 & $95.3-163.6$ & \\
2 mm displacement $(\mathrm{N})$ & & & & $208-212$ \\
Bicortical screw & $210 \pm 2.8$ & 2 & $184.6-235.4$ & $478-490$ \\
Tension band & $484 \pm 8.5$ & 6 & $407.8-560.2$ & $216-223$ \\
Handy tension band & $219.5 \pm 4.9$ & 3.5 & $175.0-264.0$ & $760-788$ \\
Malleolar screw & $774 \pm 19.8$ & 14 & $596.1-951.9$ & $208-788$ \\
Total & $421.9 \pm 247.2$ & 87.4 & $215.2-628.6$ & \\
\hline S & & & & \\
\hline
\end{tabular}

SD: Standard deviation; SE: Standard error; $\mathrm{Cl}$ : Confidence interval. 
In the ANOVA test analyses, a statistically significant difference was determined between the implants in each of the parameters of catastrophic damage force, resistance and $2 \mathrm{~mm}$ displacement force in the forces applied to the bones in the axial section (Table II).

In respect of the catastrophic damage force, new handy tension band had lower catastrophic damage of $1,245.5 \mathrm{~N}$ than the bicortical screw method ( $\mathrm{p}=0.025)$, and greater resistance of $553.5 \mathrm{~N}$ than conventional tension band $(\mathrm{p}=0.263)$, and $4,139 \mathrm{~N}$ than the malleolar screw $(\mathrm{p}<0.001)$.

When the axial force was applied and the difference between the implants was examined in respect of resistance with post-hoc analyses, new handy tension band was found to be more resistant by mean $359.6 \mathrm{~N} / \mathrm{mm}$ than the bicortical screw $(\mathrm{p}=0.010)$, by $673.9 \mathrm{~N} / \mathrm{mm}$ than conventional tension band ( $\mathrm{p}=0.001$ ), and by $1407 \mathrm{~N} / \mathrm{mm}$ than the malleolar screw method $(\mathrm{p}<0.001)$. The differences determined with all three implants were found to be statistically significant.

When the relationship between the fixation method and the $2 \mathrm{~mm}$ displacement force was examined as the axial force was applied, new handy tension band was determined to have significantly lower displacement compared to the bicortical screw $(p<0.001)$. No statistically significant difference was determined with the conventional tension band $(p=0.227)$, and it was found to be significantly high compared to the malleolar screw $(p=0.007)$.

According to the tensile force applied, with the exception of resistance, a statistically significant relationship was determined with ANOVA analysis between the methods and the parameters of catastrophic damage force and $2 \mathrm{~mm}$ displacement force (Table III).

Comparison of the methods in terms of catastrophic damage, resistance and $2 \mathrm{~mm}$ displacement according to sections of the forces is given in Figure 5, 6 and 7.

\section{DISCUSSION}

Conventional tension band wiring has been the preferred fixation method for medial malleolar fractures with smaller fragments which is not suitable for screw fixation. The most common problem encountered during tension strap cabling is the difficulty to pass through the cerclage wire semicircular bone tunnel. In these cases, cortical

TABLE II

Comparison of catastrophic damage force, resistance, and $2 \mathrm{~mm}$ displacement force of methods in axial section

\begin{tabular}{|c|c|c|c|c|c|}
\hline Axial force & Mean $\pm S D$ & SE & $95 \% \mathrm{Cl}$ & Min-Max & $p$ \\
\hline Catastrophic damage $(\mathrm{N})$ & & & & & $<0.001$ \\
\hline Bicortical screw & $7638.5 \pm 29.0$ & 20.5 & $7,378.0-7,899.0$ & $7,618.0-7,659.0$ & \\
\hline Tension band & $5,830.5 \pm 184.6$ & 130.5 & $4,172 \cdot 3-7,488.7$ & $5,700.0-5,961.0$ & \\
\hline Handy tension band & $6,384.0 \pm 445.5$ & 315.0 & $2,381.5-1,0386.5$ & $6,069.0-6,699.0$ & \\
\hline Malleolar screw & $2,245.0 \pm 134.4$ & 95.0 & $1,037.9-3,452.1$ & $2,150.0-2,340.0$ & \\
\hline Total & $5,524.5 \pm 2150.2$ & 760.2 & 3,726.9-7,322.1 & $2,150.0-7,659.0$ & \\
\hline Resistance (N/mm) & & & & & $<0.001$ \\
\hline Bicortical screw & $1,349.7 \pm 15.1$ & 10.7 & $1,213.9-1,485.4$ & $1,339.0-1,360.4$ & \\
\hline Tension band & $1,035.4 \pm 14.7$ & 10.4 & $903.3-1,167.5$ & $1,025.0-1,045.8$ & \\
\hline Handy tension band & $1,709.3 \pm 78.7$ & 55.7 & $1,002.1-2,416.6$ & $1,653.7-1,765.0$ & \\
\hline Malleolar screw & $302.3 \pm 73.8$ & 52.2 & $-361.0-965.7$ & 250.1-354.6 & \\
\hline Total & $1,099.2 \pm 555.5$ & 196.4 & $634.8-1,563.6$ & $250.1-1,765.0$ & \\
\hline 2 mm displacement $(\mathrm{N})$ & & & & & $<0.001$ \\
\hline Bicortical screw & $3,058.5 \pm 96.9$ & 68.5 & $2,188.1-3,928.9$ & $2,990.0-3,127.0$ & \\
\hline Tension band & $973.0 \pm 32.5$ & 23.0 & $680.8-1,265.2$ & $950.0-996.0$ & \\
\hline Handy tension band & $1,129.0 \pm 83.4$ & 59.0 & $379.3-1,878.7$ & $1,070.0-1,188.0$ & \\
\hline Malleolar screw & $659.0 \pm 7.1$ & 5.0 & $595.5-722.5$ & $654.0-664.0$ & \\
\hline Total & $1,454.9 \pm 1,007.4$ & 356.2 & $612.6-2,297.1$ & $654.0-3,127.0$ & \\
\hline
\end{tabular}

SD: Standard deviation; SE: Standard error; Cl: Confidence interval. 
TABLE III

Comparison of catastrophic damage force, resistance, and $2 \mathrm{~mm}$ displacement force of methods during tensile force

\begin{tabular}{|c|c|c|c|c|c|}
\hline Axial force & Mean \pm SD & SE & $95 \% \mathrm{Cl}$ & Min-Max & $p$ \\
\hline Catastrophic damage $(\mathrm{N})$ & & & & & 0,013 \\
\hline Bicortical screw & $2,094.5 \pm 122.3$ & 86.5 & $995.4-3,193.6$ & $2,008-2,181$ & \\
\hline Tension band & $1,572 \pm 28.3$ & 20 & $1,318-1,826.1$ & $1,552-1,592$ & \\
\hline Handy tension band & $1,688 \pm 144.2$ & 102 & $392-2,984$ & $1,586-1,790$ & \\
\hline Malleolar screw & $1,236 \pm 181$ & 128 & $-390.4-2,862.4$ & $1,108-1,364$ & \\
\hline Total & $1,647.6 \pm 342.7$ & 121.2 & $1,361-1,934.2$ & $1,108-2,181$ & \\
\hline Resistance (N/mm) & & & & & 0.112 \\
\hline Bicortical screw & $301.8 \pm 60.4$ & 42.7 & $-240.9-844.5$ & 259.1-344.6 & \\
\hline Tension band & $199.8 \pm 51.5$ & 36.4 & $-262.9-662.5$ & $163.4-236.2$ & \\
\hline Handy tension band & $117.4 \pm 86.3$ & 61 & $-657.6-892.4$ & $56.4-178.4$ & \\
\hline Malleolar screw & $285 \pm 35.3$ & 25 & $-32.3-602.4$ & $260.1-310$ & \\
\hline Total & $226 \pm 91.4$ & 32.3 & 149.6-302.4 & $56.4-344.6$ & \\
\hline $2 \mathrm{~mm}$ displacement $(\mathrm{N})$ & & & & & 0.008 \\
\hline Bicortical screw & $971.5 \pm 101.1$ & 71.5 & $63-1,880$ & $900-1,043$ & \\
\hline Tension band & $577 \pm 4.2$ & 3 & $538.9-615.1$ & $574-580$ & \\
\hline Handy tension band & $795 \pm 52.3$ & 37 & $324.9-1,265.1$ & $758-832$ & \\
\hline Malleolar screw & $486.5 \pm 87$ & 61.5 & $-294.9-1,267.9$ & $425-548$ & \\
\hline Total & $707.5 \pm 209.4$ & 74 & $532.4-882.6$ & $425-1043$ & \\
\hline
\end{tabular}

SD: Standard deviation; SE: Standard error; Cl: Confidence interval.

screw fixation may be necessary. Screw fixation gives sufficient results and requires removal of the implant. Therefore, new implants and designs are required when conventional tension band wiring methods

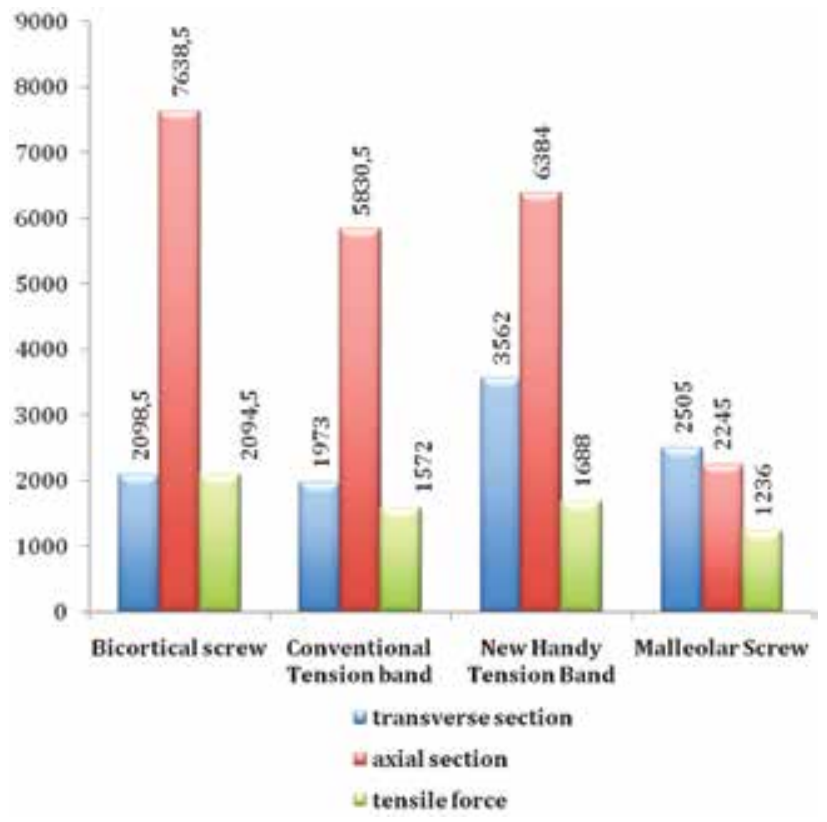

Figure 5. Comparison of methods in terms of catastrophic damage $(\mathrm{N})$ according to sections of forces. cannot be used. Orthopedic surgeons can easily create fixation systems using a K-wire during surgical procedure if necessary. In some cases, handmade implants may be extremely useful during surgery.

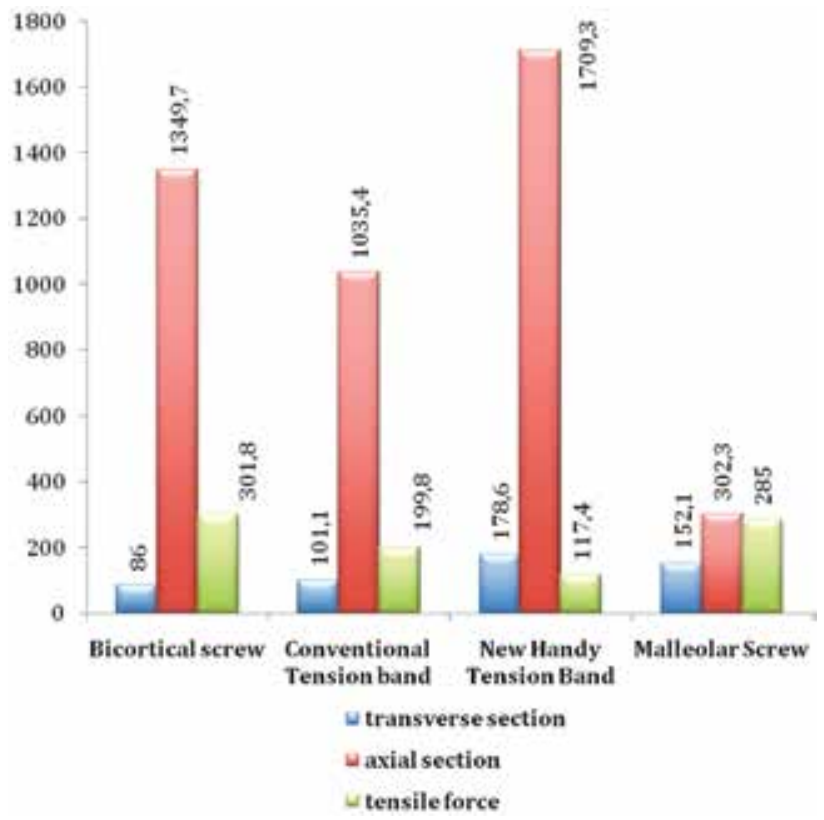

Figure 6. Comparison of methods in terms of resistance $(\mathrm{N} / \mathrm{mm})$ according to sections of forces. 


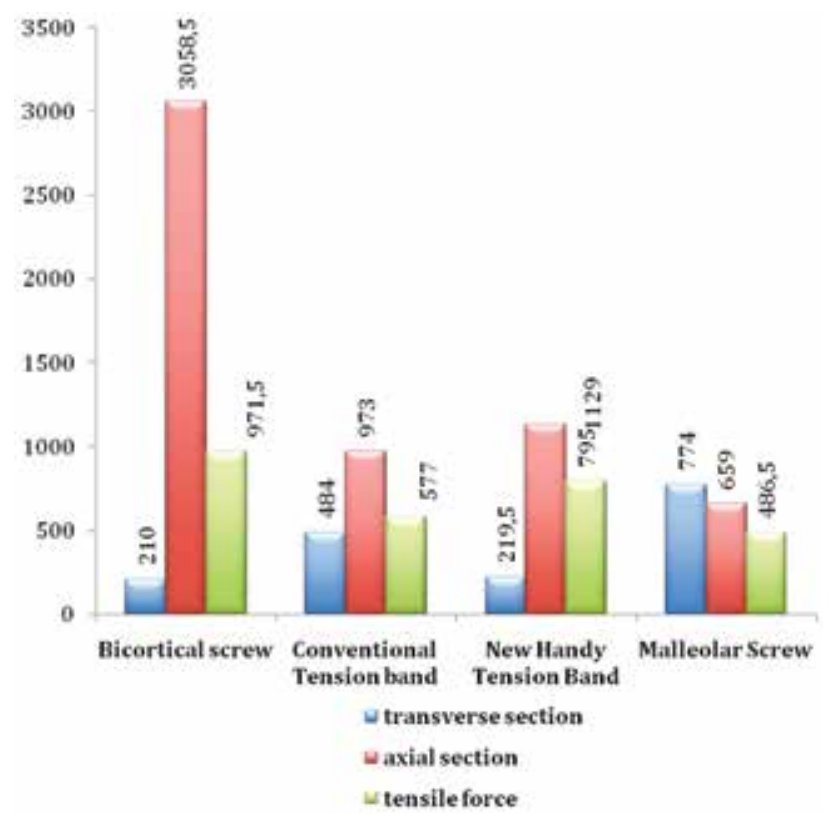

Figure 7. Comparison of methods in terms of $2 \mathrm{~mm}$ displacement $(\mathrm{N})$ according to sections of forces.

In orthopedic practice, handmade implants are widely used during patella and olecranon fractures, as well as syndesmotic repair.

Recently designed systems have been reported in the literature. In a study by Patel et al., ${ }^{[10]}$ sled fixation system (medial malleolar sled) was compared with lag screws in repair of medial malleolus fractures. The authors concluded that the new sled system may be appropriate where tension band systems are considered. Although the system developed by Patel et al. ${ }^{[10]}$ is similar to our handy tension system as a surgical procedure, in that system, proximal holes are drilled with a $2.3 \mathrm{~mm}$ bit and require the use of 2 cancellous screws with a 15 degree angle via the guide. Whereas in the new handy tension band, there are two holes, one static and one dynamic, and one screw is inserted into the preferred hole with $2.7 \mathrm{~mm}$ drill. In another study, sled system was compared with conventional malleolar screws in the surgical treatment of medial malleolus fractures. No significant difference was found between the new sled system and screws in terms of the union rate and complications. ${ }^{[15]}$

Fowler et al. ${ }^{[16]}$ examined the parameters of catastrophic damage force, resistance and $2 \mathrm{~mm}$ displacement force against transverse, axial and tensile forces in the evaluation of the biomechanical characteristics of the ankle after the application of various surgical techniques for medial malleolar fixation. According to the results of that study, bicortical screw fixation was statistically the stiffest construct under tension loading conditions compared to unicortical screw and tension band techniques with stainless steel wire.

In previous studies which have examined biomechanics after treatment with bicortical and malleolar (unicortical) screws, the bicortical screw showed $24 \%$ more resistance to tension, needed higher values for the curve axis and showed more resistance to maximum loading. ${ }^{[17,18]}$ Eck et al. ${ }^{[19]}$ determined that the resistance to tensile force was significantly higher in the bicortical screw method compared to the unicortical screw method. In the current study, no statistically significant difference was determined following the treatment with bicortical screw and unicortical screw.

Medial malleolar fractures may be seen as isolated or as a part of bimalleolar or trimalleolar fractures. The basic approach in the literature is fixation with screws along the fracture. When neutralizing plates are used together with the screw method, mechanical advantages have been shown in biomedical studies. ${ }^{[2,21]}$ Another important point is that researchers have been encouraged to seek different methods because of the need to remove implants such as bicortical screws because of the discomfort of postoperative pain felt by many patients, concomitant soft tissue damage and pain. ${ }^{[13,20]}$ The new handy tension band system may be considered as an alternative treatment with further studies in this field.

It is possible to use tension band systems in any fracture of the medial malleolus. ${ }^{[22,23]}$ We also used the new handy tension band system in medial malleolus fractures in our study.

As recommended by Clyde et al., ${ }^{[24]}$ elimination of the deficiencies of the classic tension band technique may overcome the problems of patients suffering great pain because of the operation or requiring another operation. In that study, they reported that the knotless tension band was superior to the classic tension band. The mean resistance and the value required for catastrophic damage force were found to be higher in those treated with the knotless tension band method. It was also stated that the knotless tension band was easier to use; there was potentially less irritation and the operating time was shorter. Similar results were obtained in the current study as new handy tension band system was found to have higher resistance and catastrophic damage force values than the conventional tension band. 
It is easy to apply, reduces the operation time and thus the risk of infection, and minimizes implant migration, which is usually seen with other methods. Moreover, it also reduces the skin irritation caused by the implant which is a common reason of re-operation and frequently encountered in the conventional tension band method. It was designed to provide early functional use of the ankle by providing biomechanically stable fixation.

This study has some limitations. First, the study was designed as a biomechanical study using tibias of cows. It could not be performed on human cadevers. Second limitation was the relatively small sample size. The strength of our study was to conduct a biomechanical study using a newly designed handy tension band and classical methods.

In conclusion, the results of this study showed that the recently developed new handy tension band system resisted higher forces in respect of catastrophic damage force. It was more resistant against the application of both transverse and axial force, compared to the other three implants of bicortical screw, malleolar screw and conventional tension band. Our findings should be confirmed with further research on human cadavers and randomized controlled studies to support the superiority of the new implant for the fixation of medial malleolar fractures.

\section{Declaration of conflicting interests}

The authors declared no conflicts of interest with respect to the authorship and/or publication of this article.

\section{Funding}

The authors received financial support from the Scientific Research Project of Abant İzzet Baysal University.

\section{REFERENCES}

1. Somford MP, Wiegerinck JI, Hoornenborg D, van den Bekerom MP. Ankle fracture eponyms. J Bone Joint Surg [Am] 2013;95:e198.

2. Ramsey PL, Hamilton W. Changes in tibiotalar area of contact caused by lateral talar shift. J Bone Joint Surg [Am] 1976;58:356-7.

3. Kochai A, Türker M, Çiçekli Ö, Özdemir U, Bayam L, Erkorkmaz Ü, et al. A comparative study of three commonly used fixation techniques for isolated medial malleolus fracture. Eklem Hastalik Cerrahisi 2018;29:104-9.

4. Xu HL, Liu LM, Li X, Zhang DY, Fu ZG, Wang TB, et al. Multicenter follow-up study of ankle fracture surgery. Chin Med J (Engl) 2012;125:574-8.

5. Gehr J, Friedl W. Intramedullary locked fixation and compression nail (IP-XS-Nail): treatment of ankle joint fractures. Oper Orthop Traumatol 2006;18:155-70.

6. Breederveld RS, van Straaten J, Patka P, van Mourik JC. Immediate or delayed operative treatment of fractures of the ankle. Injury 1988;19:436-8.

7. Corey RM, Cannada LK, Bledsoe G, Israel H. Biomechanical evaluation of medial malleolus fractures treated with headless compression screws. J Clin Orthop Trauma 2019;10:310-14.

8. Nieto H, Baroan C. Limits of internal fixation in long-bone fracture. Orthop Traumatol Surg Res 2017;103:61-6.

9. Varenne Y, Curado J, Asloum Y, Salle de Chou E, Colin F, Gouin F. Analysis of risk factors of the postoperative complications of surgical treatment of ankle fractures in the elderly: A series of 477 patients. Orthop Traumatol Surg Res 2016;102:245-8.

10. Patel T, Owen JR, Byrd WA, Graves RB, Chande RD, Mounasamy $\mathrm{V}$, et al. Biomechanical performance of a new device for medial malleolar fractures. Foot Ankle Int 2013;34:426-33.

11. Perren SM, Frigg R, Hehli M, Tepic S. Lag screw. In: Ruedi TP, Murphy WM, editors. AO Principles of Fracture Management. Stuttgart: Thieme; 2000. p. 157-67.

12. Ruedi TP, Murray WM. AO Principles of Fracture Management.StuttgartGermany, NY: AO Publishing; 2000.

13. Femino JE, Gruber BF, Karunakar MA. Safe zone for the placement of medial malleolar screws. J Bone Joint Surg [Am] 2007;89:133-8.

14. Ricci WM, Tornetta P, Borrelli J Jr. Lag screw fixation of medial malleolar fractures: a biomechanical, radiographic, and clinical comparison of unicortical partially threaded lag screws and bicortical fully threaded lag screws. J Orthop Trauma 2012;26:602-6.

15. Maniar H, Kempegowda H, Tawari AA, Rutter MR, Borade A, Cush G, et al. Medial Malleoli Fractures: Clinical Comparison Between Newly Designed Sled Device and Conventional Screws. Foot Ankle Spec 2017;10:296-301.

16. Fowler TT, Pugh KJ, Litsky AS, Taylor BC, French BG. Medial malleolar fractures: a biomechanical study of fixation techniques. Orthopedics 2011;34:e349-55.

17. Collinge CA, Stern S, Cordes S, Lautenschlager EP. Mechanical properties of small fragment screws. Clin Orthop Relat Res 2000;373:277-84.

18. Merk BR, Stern SH, Cordes S, Lautenschlager EP. A fatigue life analysis of small fragment screws. J Orthop Trauma 2001;15:494-9.

19. Eck JC, Walker MP, Currier BL, Chen Q, Yaszemski MJ, An KN. Biomechanical comparison of unicortical versus bicortical C1 lateral mass screw fixation. J Spinal Disord Tech 2007;20:505-8.

20. Dumigan RM, Bronson DG, Early JS. Analysis of fixation methods for vertical shear fractures of the medial malleolus. J Orthop Trauma 2006;20:687-91.

21. Barnes H, Cannada LK, Watson JT. A clinical evaluation of alternative fixation techniques for medial malleolus fractures. Injury 2014;45:1365-7.

22. Georgiadis GM, White DB. Modified tension band wiring of medial malleolar ankle fractures. Foot Ankle Int 1995;16:64-8.

23. Kanakis TE, Papadakis E, Orfanos A, Andreadakis A, Xylouris E. Figure eight tension band in the treatment of fractures and pseudarthroses of the medial malleolus. Injury 1990;21:393-7.

24. Clyde J, Kosmopoulos V, Carpenter B. A biomechanical investigation of a knotless tension band in medial malleolar fracture models in composite Sawbones ${ }^{\circledR}$. J Foot Ankle Surg 2013;52:192-4. 